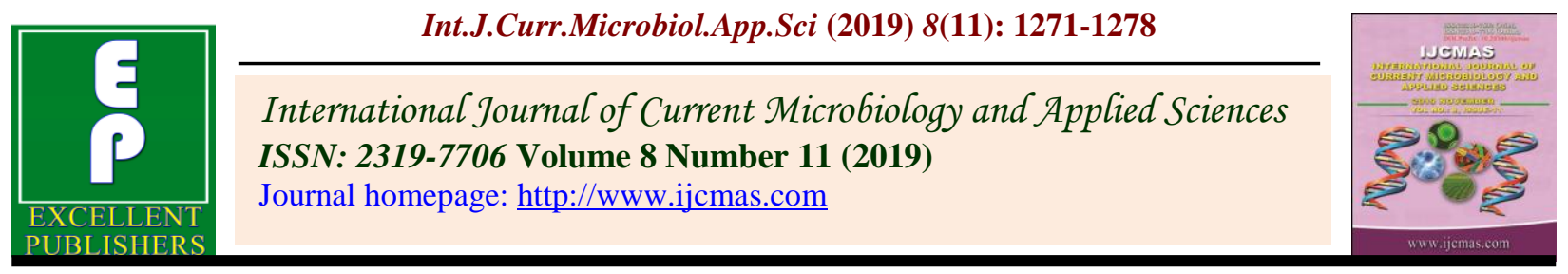

Original Research Article

https://doi.org/10.20546/ijcmas.2019.811.150

\title{
Effect of Integrated Nutrient Management on Growth and Flowering of African Marigold (Tagetes erecta) cv. Pusa Narangi Gainda
}

\author{
Ashok Kumura ${ }^{1}$, Geeta Pandey ${ }^{1 *}$, Pragnya Paramita Mishra ${ }^{1}$ and Rakesh Kumar ${ }^{2}$ \\ ${ }^{1}$ Department of Floriculture and Landscaping, College of Agriculture, OUAT, \\ Bhubaneswar-751003, India \\ ${ }^{2}$ Department of Floriculture \& Landscape Architecture, College of Horticulture, Banda \\ University of Agriculture \& Technology, Banda, Uttar Pradesh, India
}

*Corresponding author

\section{A B S T R A C T}

\section{Keywords}

African marigold, NPK, FYM, Flower diameter, Azospirillum and PSB

\section{Article Info}

Accepted:

10 October 2019

Available Online:

10 November 2019
A field experiment was conducted to study the effect of integrated nutrient management on marigold cv. Pusa Narangi Gainda at College of Agriculture, Odisha University of Agriculture and Technology, Bhubaneswar, Odisha, during 2016-17. Results revealed that treatment $\mathrm{T}_{7}(75 \% \mathrm{NPK}+\mathrm{FYM}+\mathrm{AZO}+\mathrm{PSB})$ was found to be significantly good for both vegetative and floral parameters. It recorded maximum plant height $(84.85 \mathrm{~cm})$, maximum number of primary and secondary branches $(10.03$ and 26.55 , respectively), maximum stem girth $(4.57 \mathrm{~cm})$, earliest bud initiation and flowering (31.89 days and 46.25 days, respectively) and maximum number of flowers per plant (34.40). Minimum days to 50\% flowering (50.51 days), $100 \%$ flowering (54.57 days) and maximum flower diameter $(4.87 \mathrm{~cm})$ were found in treatment $\mathrm{T}_{5}$ (75\% NPK +FYM + PSB). Flowering duration (46.22 days) and shelf life (70.67 hours) was superior with application of treatment $\mathrm{T}_{6}(75 \% \mathrm{NPK}+\mathrm{FYM}+\mathrm{AZO})$ whereas treatment $\mathrm{T}_{3}(\mathrm{AZO}+75 \% \mathrm{~N}+100 \% \mathrm{P} \& \mathrm{~K})$ reported maximum fresh weight and dry weight $(5.73 \mathrm{~g}$ and $1.50 \mathrm{~g}$, respectively). Application of 75\% NPK $(75: 150: 150 \mathrm{~kg}$ NPK /ha) in combinations with FYM (10t/ha) and biofertilizers (Azospirillum and PSB @ $5 \mathrm{~kg} / \mathrm{ha}$ ) resulted in highest yield (15.53 t/ha) with maximum net return (Rs. $1,90,794 / \mathrm{ha}$ ) and highest benefit cost ratio of 2.57 .

\section{Introduction}

Marigold, a member of the family Asteraceae, is native to Central and South America especially Mexico (Kaplan, 1960). Cultivated genera include Tagetes erecta and Tagetes patula, commonly referred to as African marigold and French marigold, respectively. African marigold is one of the most important loose flower crops grown commercially in many parts of the country. Flowers of marigold are used in garland-making, wreaths, as religious offering, in hall decoration, etc. It is in great demand as loose flower throughout 
the year. Among the various factors affecting the growth and flowering of marigold, balanced nutrition right from the beginning is very important. Though, the research over conventional nutritional requirement (NPK) in African marigold has been standardized, but farmers, for getting more quantity of flowers, add chemical fertilizers unscrupulously, which has led to enormous level of chemical build up in the ecosystem. Continuous application of imbalanced and excessive nutrients has led to decline in nutrient-use efficiency making fertilizer consumption uneconomical and producing adverse effects on atmosphere and ground water quality, causing health hazards. Integrated Nutrient Management (INM) provides an excellent opportunity to overcome all the imbalances beside sustaining soil health and enhancing crop production. The use of organic manures and bio-fertilizers along with balanced use of chemical fertilizers is known to improve the physio-chemical and biological properties of soil, besides improving the efficiency of applied fertilizers (Verma et al., 2011). Hence, keeping the importance of new age farming in mind, the present investigation was conducted to know the effect of INM in African marigold.

\section{Materials and Methods}

The present investigation was conducted at the garden of the Department of Floriculture and Landscaping, College of Agriculture, Odisha University of Agriculture and Technology, Bhubaneswar, Odisha, during 2016-17 under open field condition. The experimental land was divided into small plots of size $1.4 \mathrm{~m} \times$ $1 \mathrm{~m}$. One month old seedlings of African marigold cv. Pusa Narangi Gainda having uniform size and vigor were transplanted at a spacing of $30 \mathrm{~cm} \times 40 \mathrm{~cm}$. The treatments comprised of various combination of RDF (100:200:200 kg NPK/ha), FYM (10t/ha), biofertilizers (Azospirillum and PSB both @5 $\mathrm{kg} / \mathrm{ha}$ ) were applied as, $\mathrm{T}_{1}-100 \%$ NPK (control), $\mathrm{T}_{2}$-PSB @ 5kg/ha+75\% P + 100\% N \& K, T 3 -AZO @ 5kg/ha+75\% N +100\% P \& $\mathrm{K}, \mathrm{T}_{4}-75 \% \mathrm{NPK}+\mathrm{FYM} @ 10 \mathrm{t} / \mathrm{ha}, \mathrm{T}_{5^{-}}$75\% $\mathrm{NPK}+\mathrm{FYM} @ 10 \mathrm{t} / \mathrm{ha}+\mathrm{PSB} @ 5 \mathrm{~kg} / \mathrm{ha}, \mathrm{T}_{6^{-}}$ 75\% NPK + FYM @ 10t/ha + AZO@ 5kg/ha, $\mathrm{T}_{7}-75 \% \mathrm{NPK}+\mathrm{FYM} @$ 10t/ha + AZO@ 5kg/ha+ PSB@5kg/ha, T8-PSB @ 5kg/ha+ AZO@5kg/ha+75\% P\&N +100\% K. The experiment was laid out in randomized block design with eight treatments and three replications. All recommended package of practices were followed to raise a good crop. Data on various vegetative and flowering attributes viz., plant height $(\mathrm{cm})$, number of primary and secondary branches and stem girth $(\mathrm{cm})$, length of primary branches $(\mathrm{cm})$, leaf area $\left(\mathrm{cm}^{2}\right)$, days to bud initiation, days to flowering, days to $50 \%$ and $100 \%$ flowering, numbers of flowers per plant, flower diameter (cm), flowering duration (days), fresh weight and dry weight of flowers $(\mathrm{g})$, shelf life of flowers (days), flower yield per plant (g), per plot $(\mathrm{kg})$ and per hectare $(\mathrm{t})$ were recorded and analysed statistically.

\section{Results and Discussion}

\section{Effect of INM on vegetative parameters of African marigold}

The application of $75 \%$ of recommended dose of NPK along with FYM and bio-inoculants had a significant effect on vegetative parameters of marigold (Table 1). The treatment $\mathrm{T}_{7}(75 \% \mathrm{NPK}+\mathrm{FYM} @ 10 \mathrm{t} / \mathrm{ha}+$ AZO@ @ kg/ha + PSB@ $@ 5 \mathrm{~kg} / \mathrm{ha})$ recorded maximum plant height $(84.85 \mathrm{~cm})$, maximum number of primary and secondary branches (10.03 and 29.55 respectively) and maximum stem girth $(4.57 \mathrm{~cm})$. However, minimum plant height and stem girth was observed under $\mathrm{T}_{2}$ (PSB @ 5kg/ha $+75 \% \mathrm{P}+100 \% \mathrm{~N}$ $\& \mathrm{~K})$ while $\mathrm{T}_{4}(75 \% \mathrm{NPK}+\mathrm{FYM} @ 10 \mathrm{t} / \mathrm{ha})$ recorded minimum number of primary and secondary branches. Beneficial effect of biofertilizers and FYM in combination with 
$75 \%$ recommended dose of inorganic fertiliser might have resulted in the accumulation of more $\mathrm{N}$ in soil and more $\mathrm{N}$ uptake by the plants which might have resulted in maximum plant height. Similar findings have been reported by Majumdar et al., (2014) in gladiolus, Airadevi et al., (2012) in garland chrysanthemum; Gotmare et al., (2007) and Patel et al., (2017) in marigold. Maximum number of primary branches may be due to the effect of optimum level of NPK, biofertilizers and FYM which leads to increased level of nutrients to plant which might have enhanced the cell division and cell elongation and increase in metabolic activities in the plants. Further, it might have resulted in breaking of apical dominance and thus sprouting of axillary buds leading to more number of primary branches per plant. Similar findings have also been reported by Gotmare et al., (2007), Kumar et al., (2009) and Mittal et al., (2010) in marigold. Increase in stem girth and more number of secondary branches may be due to the effect of biofertilizers which produce the growth promoting substances such as IAA, gibberellins which enhances the soil fertility with balanced dose of inorganic fertilizers which ultimately influences increase growth and development. Similar findings were observed by Mittal et al., (2010), Gotmare et al., (2007) and Kumar et al., (2009) in marigold. Length of primary branches was highest $(50.82 \mathrm{~cm})$ under $\mathrm{T}_{1}$ (RDF) which was at par with $\mathrm{T}_{7}$ $(75 \% \mathrm{NPK}+\mathrm{FYM}+\mathrm{AZO}+\mathrm{PSB})$ and $\mathrm{T}{ }_{6}$ $(75 \% \mathrm{NPK}+\mathrm{FYM}+\mathrm{AZO})$. It may be due to immediate availability of nutrients to plants through chemical fertilizer. Increase in length of primary branches in treatments involving reduced doses of chemical fertilizers along with organic fertilizers might be attributed to the beneficial effect of biofertilizers which enhanced the process of cell division and cell elongation, which in turn might have encouraged the increase in length of primary branches. Similar findings have been reported by Gotmare et al., (2007) in marigold. Maximum leaf area $\left(30.25 \mathrm{~cm}^{2}\right)$ was observed in $\mathrm{T}_{8}$ (PSB +AZO+75\% $\mathrm{P} \& \mathrm{~N}+100 \% \quad \mathrm{~K}$ ) whereas it was found to be minimum in $\mathrm{T}_{4}$ (75\% NPK+FYM). This might be due to influence of Azospirillum which fixes the additional dose of nitrogen from the atmosphere, the chief constituent of protein essential for formation of protoplasm, which enhances the cell division and cell enlargement. PSB solubilize the fixed phosphorus in soil and helps in secretion of growth substances like auxins which enhances the better growth and development of plant. It is in conformity with the findings of Kumar $e t$ al., (2009) in African marigold and Naik et al., (2014) in carnation.

\section{Effect of INM on floral parameters of African marigold}

The different treatment combination of inorganic and organic fertilizers had significantly influenced the floral parameters (Table 2). Earliest bud initiation, earliest flowering (31.89 days and 46.25 days, respectively) and maximum number of flowers per plant (34.40) were recorded under treatment $\mathrm{T}_{7}$ (75\% NPK + FYM @ 10t/ha + AZO@5kg/ha+ PSB @ 5kg/ha). However, maximum delay in bud initiation and flowering was recorded in plants treated withT 8 (PSB @ 5kg/ha+ AZO @ 5kg/ha+ $75 \% \mathrm{P} \& \mathrm{~N}+100 \% \mathrm{~K}$ ) while minimum number of flowers per plant was recorded in $\mathrm{T}_{3}$ $(\mathrm{AZO}+75 \% \mathrm{~N}+100 \% \quad \mathrm{P} \& \mathrm{~K})$. Early bud initiation and flowering may be due to combined application of inorganic and organic fertilizers which led to amplification of nutrients especially nitrogen, phosphorus and potassium from FYM as well as recommended dose of inorganic fertilizers which prompted the translocation of phytohormones to shoots resulting in early bud initiation. Azospirillum and PSB might have indirect role which makes the nutrient readily available along with 
the presence of plant growth promoting substances which might have led to early flowering through better uptake of nutrients, thereby, plant completed its vegetative growth soon, resulting in early flowering.

These findings are in conformity with the findings of Kumar et al., (2011) in gladiolus, Naik et al., (2014) in carnation and Khanna et al., (2016) in china aster. Highest number of flowers per plant might be due to the indirect effect of the more number of branches developed by the influence of inorganic fertilizers along with organic manures and biofertilizers like PSB and Azospirillum. More number of branches resulted in more photosynthesis due to more number of leaves with enhanced food accumulation which might have resulted in better growth and subsequently higher number of flowers per plant. Similar findings have been reported by Kumar et al., (2009) in African marigold and Verma et al., (2011) in chrysanthemum.

Application of $\mathrm{T}_{5}(75 \% \mathrm{NPK}+\mathrm{FYM}+\mathrm{PSB})$ recorded minimum days to $50 \%$ and $100 \%$ flowering (50.51 days and 54.57 days, respectively) and maximum flower diameter
$(4.87 \mathrm{~cm})$ while maximum delay in $50 \%$ and $100 \%$ flowering was recorded under $\mathrm{T}_{8}$ (PSB $+\mathrm{AZO}+75 \% \mathrm{P} \& \mathrm{~N}+100 \% \mathrm{~K})$ and minimum flower diameter under $\mathrm{T}_{6}(75 \% \mathrm{NPK}+\mathrm{FYM}+$ AZO). Earliness in $50 \%$ and $100 \%$ flowering might be due to combined effect of biofertilizers and inorganic fertilizers which led to altered $\mathrm{C}$ : $\mathrm{N}$ ratio which helped in balanced management of vegetative and reproductive phases and promote early flowering.

Ultimately they resulted in better sink for faster mobilization of photosynthates and early transformation of plant parts from vegetative to reproductive phase. Similar findings have been reported by Thumar et al., (2013) in marigold and Naik et al., (2014) in carnation. Increased flower diameter might be due to combined effect of organic and inorganic fertilizers. PSB possess the ability to bring sparingly insoluble inorganic or organic phosphates into soluble form by secreting organic acids which can also contribute to improving flower diameter. Similar findings were reported by Kumar et al., (2009), Thumar et al., (2013) and Patel et al., (2017) in African marigold.

Table.1 Effect of integrated nutrient management on vegetative parameters of African marigold cv. Pusa Narangi Gainda

\begin{tabular}{|c|c|c|c|c|c|c|}
\hline Treatments & $\begin{array}{c}\text { Plant } \\
\text { height } \\
(\mathbf{c m})\end{array}$ & $\begin{array}{c}\text { Number of } \\
\text { primary } \\
\text { branches }\end{array}$ & $\begin{array}{c}\text { Length of } \\
\text { primary } \\
\text { branches } \mathbf{( c m )}\end{array}$ & $\begin{array}{c}\text { Number of } \\
\text { secondary } \\
\text { branches }\end{array}$ & $\begin{array}{c}\text { Leaf area } \\
\left(\mathbf{c m}^{\mathbf{2}}\right)\end{array}$ & $\begin{array}{c}\text { Stem } \\
\text { girth } \\
(\mathbf{c m})\end{array}$ \\
\hline $\mathbf{T}_{\mathbf{1}}$ & 82.39 & 9.20 & 50.82 & 24.88 & 25.00 & 4.32 \\
\hline $\mathbf{T}_{\mathbf{2}}$ & 75.32 & 8.13 & 45.16 & 25.22 & 24.84 & 3.47 \\
\hline $\mathbf{T}_{\mathbf{3}}$ & 76.46 & 8.37 & 46.77 & 24.22 & 25.04 & 3.63 \\
\hline $\mathbf{T}_{\mathbf{4}}$ & 77.47 & 7.93 & 45.88 & 24.11 & 24.28 & 3.77 \\
\hline $\mathbf{T}_{\mathbf{5}}$ & 78.00 & 9.73 & 45.47 & 25.99 & 27.18 & 4.36 \\
\hline $\mathbf{T}_{\mathbf{6}}$ & 80.33 & 8.83 & 49.03 & 25.55 & 26.57 & 4.25 \\
\hline $\mathbf{T}_{\mathbf{7}}$ & 84.85 & 10.03 & 49.40 & 26.55 & 29.17 & 4.57 \\
\hline $\mathbf{T}_{\mathbf{8}}$ & 78.17 & 8.50 & 47.62 & 24.55 & 30.00 & 4.10 \\
\hline $\mathbf{S E m} \mathbf{S}$ & 1.46 & 0.21 & 1.38 & 0.72 & 0.73 & 0.08 \\
\hline $\mathbf{C D} \mathbf{5 \%} \boldsymbol{( 5 \%}$ & 4.44 & 0.65 & 4.20 & 2.21 & 2.20 & 0.24 \\
\hline
\end{tabular}


Table.2 Effect of integrated nutrient management on floral parameters of African marigold cv. Pusa Narangi Gainda

\begin{tabular}{|c|c|c|c|c|c|c|c|c|c|c|}
\hline Treatments & $\begin{array}{l}\text { Days to } \\
\text { bud } \\
\text { initiation }\end{array}$ & $\begin{array}{l}\text { Days to } \\
\text { flowering }\end{array}$ & $\begin{array}{c}\text { Days to } 50 \\
\text { percent } \\
\text { flowering }\end{array}$ & $\begin{array}{c}\text { Days to } 100 \\
\text { percent } \\
\text { flowering }\end{array}$ & $\begin{array}{l}\text { Flower } \\
\text { diameter } \\
(\mathbf{c m})\end{array}$ & $\begin{array}{c}\text { Number } \\
\text { of } \\
\text { flowers/ } \\
\text { plant }\end{array}$ & $\begin{array}{c}\text { Flowering } \\
\text { duration } \\
\text { (days) }\end{array}$ & $\begin{array}{l}\text { Fresh } \\
\text { weight of } \\
\text { flower } \\
\text { (g) }\end{array}$ & $\begin{array}{c}\text { Dry } \\
\text { weight of } \\
\text { flower } \\
\text { (g) }\end{array}$ & $\begin{array}{c}\text { Shelf life } \\
\text { (hours) }\end{array}$ \\
\hline $\mathbf{T}_{1}$ & 32.97 & 47.05 & 51.53 & 56.01 & 4.50 & 29.73 & 44.04 & 4.35 & 1.19 & 59.00 \\
\hline $\mathbf{T}_{2}$ & 34.63 & 50.63 & 55.09 & 59.07 & 4.17 & 29.60 & 43.11 & 5.04 & 1.16 & 58.33 \\
\hline $\mathbf{T}_{3}$ & 33.04 & 50.09 & 54.45 & 58.54 & 4.37 & 28.07 & 45.33 & 5.73 & 1.50 & 60.67 \\
\hline $\mathbf{T}_{4}$ & 34.44 & 50.89 & 55.36 & 59.76 & 4.30 & 31.17 & 45.00 & 4.96 & 1.07 & 62.33 \\
\hline $\mathbf{T}_{5}$ & 33.89 & 46.92 & 50.51 & 54.57 & 4.87 & 32.07 & 43.82 & 4.58 & 1.12 & 64.00 \\
\hline $\mathbf{T}_{6}$ & 34.07 & 48.45 & 52.77 & 56.77 & 4.10 & 32.63 & 46.22 & 5.55 & 1.36 & 70.67 \\
\hline $\mathbf{T}_{7}$ & 31.89 & 46.25 & 51.22 & 55.33 & 4.67 & 34.40 & 45.66 & 5.25 & 1.23 & 68.00 \\
\hline $\mathbf{T}_{8}$ & 35.08 & 51.01 & 55.82 & 59.78 & 4.80 & 29.10 & 43.44 & 4.33 & 1.03 & 69.33 \\
\hline SEm \pm & 0.56 & 0.60 & 0.57 & 1.30 & 0.08 & 0.61 & 0.52 & 0.16 & 0.04 & 1.29 \\
\hline CD (5\%) & 1.27 & 1.83 & 1.73 & 3.95 & 0.26 & 1.81 & 1.59 & 0.49 & 0.13 & 3.93 \\
\hline
\end{tabular}

Table.3 Effect of integrated nutrient management on yield and economics of African marigold cv. Pusa Narangi Gainda

\begin{tabular}{|c|c|c|c|c|c|c|c|}
\hline Treatments & $\begin{array}{c}\text { Flower } \\
\text { yield/plant }\end{array}$ & $\begin{array}{c}\text { Flower } \\
\text { yield/plot } \\
(\mathbf{g})\end{array}$ & $\begin{array}{c}\text { Flower } \\
\text { yield/ ha } \\
\text { (kg) }\end{array}$ & $\begin{array}{c}\text { Total cost of } \\
\text { production } \\
\text { (Rs.) }\end{array}$ & $\begin{array}{c}\text { Gross return } \\
\text { (Rs.) }\end{array}$ & $\begin{array}{c}\text { Net return } \\
\text { (Rs.) }\end{array}$ & $\begin{array}{c}\text { Benefit : } \\
\text { Cost }\end{array}$ \\
\hline $\mathbf{T}_{\mathbf{1}}$ & 127.19 & 1.91 & 13.62 & $1,08,358.00$ & $2,72,448.00$ & $1,64,090.00$ & 2.51 \\
\hline $\mathbf{T}_{\mathbf{2}}$ & 125.38 & 1.88 & 13.43 & $1,06,539.00$ & $2,68,557.00$ & $1,62,017.00$ & 2.52 \\
\hline $\mathbf{T}_{\mathbf{3}}$ & 128.10 & 1.92 & 13.72 & $1,08,642.00$ & $2,74,390.00$ & $1,65,748.00$ & 2.53 \\
\hline $\mathbf{T}_{\mathbf{4}}$ & 127.67 & 1.92 & 13.67 & $1,20,206.00$ & $2,73,462.00$ & $1,53,256.00$ & 2.27 \\
\hline $\mathbf{T}_{\mathbf{5}}$ & 136.50 & 2.05 & 14.62 & $1,20,806.00$ & $2,92,383.00$ & $1,71,577.00$ & 2.42 \\
\hline $\mathbf{T}_{\mathbf{6}}$ & 142.48 & 2.14 & 15.26 & $120,806.00$ & $3,05,185.00$ & $1,84,379.00$ & 2.53 \\
\hline $\mathbf{T}_{\mathbf{7}}$ & 145.03 & 2.18 & 15.53 & $1,21,406.00$ & $3,12,200.00$ & $1,90,794.00$ & 2.57 \\
\hline $\mathbf{T}_{\mathbf{8}}$ & 128.10 & 1.92 & 13.72 & $1,06,813.00$ & $2,71,540.00$ & $1,64,727.00$ & 2.54 \\
\hline $\mathbf{S E m} \pm$ & 4.554 & 0.07 & 0.49 & & & & \\
\hline $\mathbf{C D} \mathbf{5 \%}$ & 13.78 & 0.20 & 1.47 & & & & \\
\hline
\end{tabular}


Maximum flowering duration (46.22 days) and longest shelf life $(70.67 \mathrm{hrs}$.) was reported in plants treated with $\mathrm{T}_{6}(75 \% \mathrm{NPK}+\mathrm{FYM}+$ Azospirillium) while they were minimum in $\mathrm{T}_{2}$ (PSB $+75 \% \mathrm{P}+100 \% \mathrm{~N} \& \mathrm{~K})$. Maximum flowering duration may be due to combined application of inorganic fertilizers along with organic and biofertilizers. It might be ascribed to easy uptake of nutrients and simultaneous transport of growth promoting substances like cytokinins to the axillary buds resulting in breakage of apical dominance.

Ultimately they resulted in better sink for faster mobilization of photosynthates. Similar findings have been reported by Palagni et al., (2013) in chrysanthemum and Chaudhary et al., (2013) in gladiolus.

Increased shelf life may be due to optimum food nutrient availability from different organic and inorganic sources which might have resulted in greater development of water conducting tissue with high level of water retention in the cells of flowers thereby lowering the desiccation. Similar findings have been reported by Khanna et al., (2016) in china aster and Verma et al., (2011) chrysanthemum. The fresh and dry weight of flowers were found to be maximum $(5.73 \mathrm{~g}$ and $1.50 \mathrm{~g}$, respectively) under $\mathrm{T}_{3}(\mathrm{AZO}+75 \%$ $\mathrm{N}+100 \% \mathrm{P} \& \mathrm{~K})$ while they were minimum in treatment $\mathrm{T}_{8} \quad(\mathrm{PSB}+\mathrm{AZO}+75 \% \quad \mathrm{P} \& \mathrm{~N}+100 \%$ $\mathrm{K})$.

This might be due to the presence of ammonium from two different sources viz, Azospirillium and chemical fertilizer which might have participated in higher protein synthesis and thus improved the vegetative growth, dry matter accumulation and partitioning of nutrients towards the developing flower buds. Similar findings have been reported by Kumar et al., (2009) in African marigold and Sarwa et al., (2014) in petunia.

\section{Effect of INM on yield of African marigold flowers}

Maximum flower yield per plant, per plot and per hectare $(145.03 \mathrm{~g}, 2.18 \mathrm{~kg}$ and $15.53 \mathrm{t}$, respectively) was obtained in $\mathrm{T}_{7}(75 \% \mathrm{NPK}+$ $\mathrm{FYM}+\mathrm{AZO}+\mathrm{PSB}$ ) whereas minimum results for these parameters were found in $\mathrm{T}_{2}$ (PSB $+75 \% \mathrm{P}+100 \% \mathrm{~N} \& \mathrm{~K})$. It might be due to the fact that bio-fertilizers enhance growth promoting substances such as IAA, gibberellins like substances, vitamins, riboflavins etc. which might have enhanced the soil fertility. Bio-fertilizer when applied with organic and inorganic fertilizers has increased the availability of essential plant nutrients which might have enhanced root and shoot development thereby increasing the growth and yield. Thereafter it might have influenced the reproductive phase and induced flowering which resulted in increased number of flower yield per plant, per plot and per hectare. Similar findings has been reported by Mittal et al., (2010), Thumar et al., (2013) and Patel et al., (2017) in African marigold and Airadevi et al., (2012) in garland chrysanthemum.

\section{Effect of INM on economics of African marigold flowers}

The cost of production of marigold in the present investigation ranged from Rs. 1,06,539 $\left(\mathrm{T}_{2}\right)$ to Rs. 1,21,406 in $\mathrm{T}_{7}$ whereas the net return varied from Rs. 1,62,017 $\left(\mathrm{T}_{2}\right)$ to Rs.1,90,794 $\left(\mathrm{T}_{7}\right)$. The maximum benefit cost ratio (2.57) was obtained in $\mathrm{T}_{7}(75 \%$ $\mathrm{NPK}+\mathrm{FYM}+\mathrm{AZO}+\mathrm{PSB}$ ) which might be due to production of maximum number of quality flower under this treatment, fetching better price thus increasing net return as compared to other treatments.

\section{References}

Airadevi, P.A. and Mathad, J.C., 2012. Effect of INM on growth, yield and 
economics of garland chrysanthemum. Asian Journal of Soil Science, 7(1): 93-97.

Chaudhary, N., Swaroop, K., Janakiram, T., Biswa, D.R., and Singh, G. 2013. Effect of integrated nutrient management on vegetative growth and flowering characters of gladiolus. Indian Journal Horticulture, 70(1): 156-159.

Gotmare, P.T., Damke, M.M., Gonge, V.S. and Deshmukh, S. 2007. Influence of integrated nutrient management on vegetative growth parameters of marigold (Tagetes erecta L.). Asian Journal of Horticulture, 2(2): 33-36.

Kaplan, L. 1960. Marigold. In: Commercial Flower, (Eds. Bose, T. K. and Yadav, L. P.), Naya Prokash, Calcutta, pp. 714.

Khanna, P., Rajesh, Bohra, M., Punetha, P. and Nautiyal, B.P. 2016. Studies on the effect of organic manures and PSB on vegetative and floral parameters of China aster (Callistephus Chinensis (L.) ness.) cv. Kamini under mid hills region of Himalaya. The Bioscan, 11(4): 2707-2710.

Kumar, R., Kumar, R. and Kumar, P. 2011. Effect of integrated use of chemical fertilizers, biofertilizers and biostimulants in gladiolus (Gladiolus grandiflorus L.) cv. Sancerre. Progressive Horticulture, 43(1):149152.

Kumar, D., Singh, B. P., Singh, V.N. 2009. Effect of integrated nutrient management on growth, flowering behaviour and yield of African marigold (Tagetes erecta L.) cv. African Giant Double Orange. Journal of Horticultural Sciences, 4(2):134137.

Majumder, J., Sellam, P., Tiwari, A.K., Saha, T.N. and Kumar, R. 2014. Integrated nutrient management in commercial flower crops. Progressive Research, 9 (1): 28-32.

Mittal, R., Patel, C., Nayee, D.D., and Sitapara, H.H. 2010. Effect of integrated nutrient management on growth and yield of African marigold (Tagetes erecta L.) cv. 'Local' under middle Gujarat agro-climatic conditions. Asian Journal of Horticulture, 5(2): 347-349.

Naik, B.H and Dalawai, B. 2014. Integrated nutrient management studies in carnation (Dianthus caryophyllus L.) cv. Soto under protected condition. International Journal of Agricultural Sciences and Veterinary Medicines, 2(3):19-24.

Palagani N., Brad, A.V., Bhosale, N. and Thakur, B.V. 2013. Influence of integrated plant nutrition on growth and flower yield of chrysanthemum (Chrysanthemum morifolium Ramat.) cv. IIHR-6 under saurashtra condition. Asian Journal of Horticulture, 8(2):502-506.

Patel, V., Patel, G.D., Desai, K.D., Desai, M. and Patel, U. 2017. Integrated nutrient management in African marigold (Tagetes erecta L.). International Journal of Chemical Studies, 5(4): 1352-1354.

Sarwa, P.C., Soni, M., Vaidya, P.P. and Khandekar, J.S. 2014. Effect of Azotobacter, Azospirillum and different level of inorganic fertilizer on growth and flowering of petunia. Asian Journal of Horticulture, 9(1): 61-63.

Thumar, B.V., Barad, A.V., Neelima, P., Bhosale, N. 2013. Effect of integrated system of plant nutrition management on growth, yield and flower quality of African marigold (Tagetes erecta L.) cv. Pusa Narangi. Asian Journal of Horticulture, 8(2): 466-469.

Verma, S.K., Angadi, S.G., Patil, V.S., Mokashi, A.N., Mathad, J.C., and 
Mummigatti, U.V. 2011. Growth, yield and quality of chrysanthemum (Chrysanthemum morifolium Ramat.) cv. Raja as influenced by integrated nutrient management. Karnataka Journal of Agricultural Sciences, 24(5): 681-683.

\section{How to cite this article:}

Ashok Kumura, Geeta Pandey, Pragnya Paramita Mishra and Rakesh Kumar. 2019. Effect of Integrated Nutrient Management on Growth and Flowering of African Marigold (Tagetes erecta) cv. Pusa Narangi Gainda. Int.J.Curr.Microbiol.App.Sci. 8(11): 1271-1278. doi: https://doi.org/10.20546/ijcmas.2019.811.150 